Discussion Paper No. 02-60

\title{
The Rationale for Wage Rigidity: Survey Evidence from German and US Firms
}

Wolfgang Franz and Friedhelm Pfeiffer

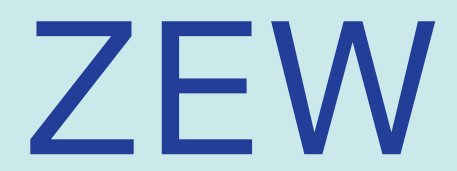

Zentrum für Europäische Wirtschaftsforschung GmbH

Centre for European

Economic Research 
Discussion Paper No. 02-60

\title{
The Rationale for Wage Rigidity: Survey Evidence from German and US Firms
}

\author{
Wolfgang Franz and Friedhelm Pfeiffer
}

Download this ZEW Discussion Paper from our ftp server:

ftp://ftp.zew.de/pub/zew-docs/dp/dp0260.pdf

Die Discussion Papers dienen einer möglichst schnellen Verbreitung von neueren Forschungsarbeiten des ZEW. Die Beiträge liegen in alleiniger Verantwortung der Autoren und stellen nicht notwendigerweise die Meinung des ZEW dar.

Discussion Papers are intended to make results of ZEW research promptly available to other economists in order to encourage discussion and suggestions for revisions. The authors are solely responsible for the contents which do not necessarily represent the opinion of the ZEW. 


\section{Non technical summary}

This study joins the literature which investigates the empirical relevance of prominent explanations for wage rigidity, such as contract theory, implicit contract theory, efficiency wage theories, fair wage theory and insider-outsider theory. Our study extends the existing literature by basing the findings on thorough econometric methods and a more adequate, because larger and randomly selected, data set. In addition, we analyze the statistical correlation between various explanations for wage rigidity, because, say, two different explanations may by themselves provide a rationale for not cutting wages on their own, but lose part of their explanatory power when both are relevant. Furthermore we compare explanations for wage rigidity between Germany and the United States, two countries with diverse labor market legislation.

While the economic rationale for wage rigidity may be independent of national legislation, the relevance of each of these explanations may not. Depending on national labor legislation the role of any of these explanations for wage rigidity may differ. The bargaining power of employees and their unions will depend on employment protection, codetermination and collective wage bargaining legislation. Since German workers enjoy a higher degree of employment protection than American workers do and codetermination and collective bargaining is quite common in Germany, their bargaining power might be higher, especially in collective wage bargaining rounds. Differences in legislation may also indirectly influence the relevance of efficiency wage explanations for wage rigidity, because more strict employment protection legislation or a wider application of labor union contracts might impose more restrictions on firms wage policies.

We surveyed 801 German firms and asked for their viewpoint with respect to the relevance of various explanations for wage rigidity. Moreover, we compared our results with those obtained by Campbell and Kamlani (1997) for the United States, but taking into account legal peculiarities of the German labor market system for wage determination. German firms strongly support labor union contracts as an explanation for wage rigidity for (less) skilled workers. Specific human capital and negative signals for new hires received strong support for highly skilled employees. Campbell and Kamlani (1997) found the strongest support for the adverse selection model as applied to quits for highly skilled white collar workers. This is not the case in our study, which seems to be the consequence of stronger employment protection legislation in Germany.

In both countries firms support implicit contract theory as an explanation for wage rigidity for less skilled worker as well as turnover costs and a negative influence of wage reduction on workers effort for all skill groups. Compared to the US-evidence, insider-outsider behavior and labor union contracts are more relevant for the explana- 
tion of wage rigidity from the viewpoint of German firms, which hints to the higher degree of unionization in Germany compared to the United States. The German experience has some similarities with the Swedish (Agell and Bennmarker, 2002, Agell and Lundborg, 2002), where unionization is even higher than in Germany. Despite the influence of labor market institutions and labor legislation, however, the economic rationale for wage rigidity has its own weight. The support from German and US firms for explanations based on the impact of wages on effort and implicit contract theory is not that different.

Different causes of wage rigidity are related to each other. There is a positive correlation between labor union contracts and implicit contracts explanations for wage igidity for all skill groups. This finding suggests that workers' desire for stable wages is met in part by labor union contracts. There is also a relatively high correlation between five causes based on variants of efficiency wage theories. The findings suggest that the contribution of an additional version of efficiency wages for explaining wage rigidity is rather small, although each of the five causes received a high average score. Furthermore, labor union contracts and efficiency wage explanations provide a ationale for wage rigidity on its own. Labor union contracts are no substitute for efficiency wage explanations on wage rigidity and efficiency wage explanations provide no substitute for implicit contracts. Each of these three basic theoretical explanations contributes independently to the understanding of wage rigidity in firms. 


\title{
The Rationale for Wage Rigidity: Survey Evidence from German and US Firms*
}

\author{
by \\ Wolfgang Franz and Friedhelm Pfeiffer \\ Center for European Economic Research, ZEW, Mannheim
}

\begin{abstract}
The study provides evidence for the rationale of wage rigidity in Germany compared to the United States. Based on a survey of 801 firms, we extend the study of Campbell and Kanlani (1997, this journal) by using more thorough econometric methods, for example, and find strong support for explanations based on labor union contracts and implicit wages for Germany. Furthermore, survey respondents indicated that labor union contracts and implicit contracts are important reasons for wage rigidity for the (less) skilled. Specific human capital and negative signals for new hires are important reasons for the highly skilled. In contrast to the US experience for German firms insider-outsider behavior, labor union contracts and specific human capital seem to be more important explanations of wage rigidity.
\end{abstract}

Keywords: wage rigidity, labour union contracts, efficiency wage theory, implicit contract theory.

JEL-Classification: J41, J51, K31

\section{*Acknowledegment}

The authors gratefully acknowledge financial support from the German Science Foundation (Deutsche Forschungsgemeinschaft) under grant FR 715/3-1, FR 715/3-2. We would like to thank Bernhard Bookmann, Bernd Fitzenberger, Norbert Janz, Joachim Möller, Walter Oechsler, Winfried Pohlmeier and Volker Rieble for many valuable comments. The usual disclaimer applies. 


\section{Introduction}

Despite high unemployment rates, firms in Germany as well as in other industrialized countries seldom seem to cut wages even if they are not bound by negotiated wage contracts. The same observation holds with respect to industry level wage bargaining rounds in Germany. Negotiated wages, as a rule, never decline. In recessions, hours reduction and workers displacement are more common adjustment mechanisms rather than wage reductions. The question is why societies afford the luxury of wage rigidity, given the significant costs of unemployment. ${ }^{1}$

Several studies try to shed light on the relevance of theoretical explanations for the reasons of wage rigidity. ${ }^{2}$ A special branch of these attempts contributes to the literature by asking firms why they behave the way they do (Table I). ${ }^{3}$ These studies indicate that economic theory provides sound explanations for wage rigidity, among them efficiency wage theories, contract and implicit contracts theory and fairness theory.

Note, however, that sample sizes in most of these studies are rather small and often not representative for firms in question. Furthermore, information concerning the type of labor contracts is rare. Kaufman (1984) interviewed 26 small firms in Britain, Blinder and Choi (1990) 19 large firms in New Jersey and Eastern Pennsylvania. Campbell and Kamlani (1997) focus on five prominent explanations of wage rigidity (contract theory, implicit contract theory, efficiency wage theories, fair wage theory and insider-outsider theory) and introduced three skill categories of labor. Their study is based on a survey of 184 mainly large US firms. Agell and Lundborg (1995, 2002) surveyed 159 relatively large unionized firms from the Swedish manufacturing sector in 1991 and again in 1998. In a further study, Agell and Bennmarker (2002) interviewed 885 representatively selected Swedish firms in 1999. Bewley $(1995,1998$, 1999) interviewed 335 business and union leaders, counselors of unemployed persons and business consultants in the Northeast of the United States. The latter sam-

\footnotetext{
${ }^{1}$ Bertola (1999) compares employment, unemployment and wage dynamics in a number of industrialized countries, among them Germany and the United States. On the aggregate level real wages in Germany increased considerably in the last forty years. There was only moderate employment growth. In the United States, there was a significant rise in employment accompanied by a moderate rise in real wages.

${ }^{2}$ See Bewley (1999), Malcomson (1999) and Howitt (2002) for recent comprehensive discussions of empirical and theoretical work on wage rigidity.

${ }^{3}$ Recent evidence on the existence of nominal wage rigidity based on individual workers pay histories is provided by Altonji and Devereux (1999), Card and Hyslop (1997) and Kahn (1997) for the United States, Beissinger and Knoppik (2001) for Germany and Fehr and Götte (2000) for Switzerland, among others.
} 
ple was obtained by net working and not by random sampling strategies. Moreover, due to differences in the questionnaires and the research methods used, the findings are not easily comparable between those studies.

Our study comes closest to the methodology employed by Campbell and Kamlani (1997) but extends their work in several important ways. Firstly, while the design of our questionnaire deliberately also contains the questions, among others, raised by these authors, in order to allow a direct comparison, we base our findings on thorough econometric methods and a more adequate, because larger and randomly selected (like Agell and Bennmarker (2002), which has been conducted also in 1999), data set. In our study the influence of firm specific factors and labor contracts on the assessment of different explanations of wage rigidity is tested using multivariate ordered probit models rather than by bivariate t-tests. Moreover, we analyze the statistical correlation between different explanations for wage rigidity. While Campbell and Kamlani (1997) asked firms to indicate the most important statement for explaining wage rigidity our correlation analyses offer an attempt to study the relationship between different explanations. This aspect seems important because, say, efficiency wage theories and contract theory may by themselves provide a rationale for not cutting wages on their own, but if firms view labor union contracts as an important explanation for wage rigidity, efficiency wages may, from the viewpoint of firms, lose part of their explanatory power. Whether that is the case or not, is an empirical question, which is investigated in our study. Secondly, although firms in Germany and the U.S. share many common interests and belong to roughly comparable economic environments, they differ remarkably in their assessment of the causes of wage rigidity. As has been pointed out, e.g. by Howitt (2002), alternative explanations for wage stickiness are central to the great macroeconomic debates. As a prerequisite for constructing macroeconomic models, an understanding of the forces which prevent hbor markets from clearing is essential.

The paper is organized as follows. Section II describes the German survey and some peculiarities of the structure of wage contracts. Section III discusses firm responses with respect to distinct explanations of wage rigidity and compares the results with the ones found by Campbell and Kamlani (1997) for the United States. Section IV highlights the relationship between firm support for each of the statements on wage rigidity. Section V investigates the issue of pay differentiation in labor union contracts. In section VI we present our conclusions. 


\section{Overview of the German survey and structure of contracts}

Between February and April 2000, 801 firms responded to a standardized written questionnaire which was sent to the head of the human resources department of 5,158 firms (each with more than 9 employees) from the following industries: chemical; metal, electrical goods industry and machinery; wholesale and retail trade; finance and insurance; firm related services and other sectors. Firms were selected randomly from about 160,000 firms operating in these industries. Details of the sample design are relegated to the Appendix. The response rate was 15.5 percent and item response is high.

Table II contains descriptive statistics about the sample population and the respective population of all firms. To begin with, firms which apply union labor contracts are somewhat overrepresented in the sample (75 percent versus 40 percent) and represent around 70 percent of sample employees. Either these firms are covered by industry level bargaining, i.e. they are members of the bargaining employer association, or, to a much lesser amount (10 percent) they apply union labor contracts on a voluntary basis, in order to avoid costs associated with wage bargaining, for example. Be that as it may, application of union labor contracts rises with firm size. To be covered by collective bargaining does not necessarily mean, however, that wage determination at the firm level is absent. In 83 percent of the firms wages are bargained between employer and workers either as an alternative or in addition to labor union contracts. Both elements, industry level and individual firm level wage bargaining, can be observed frequently at the same firm.

Taken together, there is a stronger emphasis on industry level wage bargaining in Germany compared to the United States. Although firms covered by industry level bargaining are not forced legally to pay their non-union workforce wages as high as negotiated, as a rule, most firms do so for obvious reasons (e.g. otherwise the employees would join the union). Around 87 and 80 percent, respectively, of the survey firms with labor union contracts responded that they had no factories where labor union contracts were not applied and that their pay schemes did not differ between 
union and non union workers (Table II). ${ }^{4}$ These figures differ remarkably from those in the United States according to Campbell and Kamlani (1997). ${ }^{5}$

The causes of wage rigidity may be subject to firm heterogeneity as has been emphasized by Bewley (1999). Hence, the survey tries to capture essential parts of such heterogeneity. The reasons for wage rigidity might differ between firms with and without labor union contracts as well as with respect to industry affiliation, firm size, skill level of the workforce, regional location of the (headquarter of the) firm and whether firms have difficulties recruiting new staff, pointing to the labor market situation as an influence of firms responses. Analogous to Campbell and Kamlani (1997) we distinguish three broad skill categories - highly skilled, skilled and less skilled. Less skilled are defined as workers without a formal occupational degree, skilled are workers who have been certified by the German Dual Vocational Training System, and highly skilled are workers with a degree from a university or a technical university. While the categories are the same in both studies, their definitions differ because those used in this study are better suited to the German educational system. For example, in contrast to the United States the majority of blue-collar workers in Germany have been educated in the German Dual Vocational Training System and should be categorized as being skilled workers. Hence, in the German survey the share of skilled workers is higher than in the U.S.. The industrial composition between both countries is similar with respect to manufacturing and trade. In the German survey, however, there are more firms belonging to the firm-related service sector, and less firms belonging to finance, insurance, and construction. Finally, in Germany, average firm size is smaller.

\section{Explanations for wage rigidity by German and US-firms}

Firms were given nine statements based on various theories of wage rigidity as in Campbell and Kamlani (1997, part III) ${ }^{6}$ The introductory statement was: "Even in economically bad times or in times of high unemployment firms seldom reduce

\footnotetext{
${ }^{4}$ From a legal point of view, firms with labor union contracts have to apply them only to members of the bargaining union. 30 percent of the workforce population in Germany is a member of a union (Franz (1999) p. 242).

${ }^{5}$ According to Campbell and Kamlani (1997, Footnote 1), 12.3 percent of workers in the United States are represented by labor unions. In their sample 14.7 percent of the firms are unionized. Although union membership declined in Germany (see Franz (1999) p. 242 ff.) as well as in the United States and Great Britain (see Acemoglu et al. (2001)) the application of labor union contracts in Germany is rather stable. For example: in the finance and insurance industries only 14 percent of workers are unionized; however, 70 percent of the firms apply the labor union contracts to almost all relevant workers.

${ }^{6}$ The questionnaire is available on request.
} 
workers pay, although that may help them to survive and save working places. Please assess the following explanations as 'not important', 'of minor importance', 'moderately important' or 'very important'. Respondents were asked to assess the statements for each of the three worker categories separately.

Table III reports the frequency distribution of the responses for the nine statements, two values of the average scores - one for the sample and one for the population of firms (under the assumption of random response) and the average scores from Campbell and Kamlani (1997, Table IV). The responses to statement $a$ (labor union contracts) are reported separately for the groups of firms with labor union contracts. In order to allow for comparison with Campbell and Kamlani (1997), the four responses were converted into numerical scores 1 (not important), 2 (of minor importance), 3 (moderately important) and 4 (very important). An average score over 2.5 is considered as strong and an average over 3.0 as very strong support (see Blinder (1990)). In addition, Table III reports the whole frequency distribution of results. For example, statement $a$ (emphasizing labor union contracts as a reason for wage rigidity) received the highest score for less skilled workers. Nevertheless, for some 19 percent of survey firms applying labor union contracts, negotiated wages were unimportant or of minor importance for the explanation of wage rigidity. The significance of firm characteristics is tested with multivariate ordered probit models. Summary results are reported in Table V. This methodology may document the relevance of firm characteristics more appropriately than bivariate t-tests of scores as in Campbell and Kamlani (1997), given the numerical conversions of qualitative statements and a possible presence of multicollinearity.

Firms in Germany and in the United States share common views but differ in others. In both countries the reasons for wage rigidity differ between skill groups. In Germany statement $a$ (labor union contracts) and $b$ (implicit contracts) received (very) strong support for less and medium skilled workers, but for many more German respondents labor union contracts are a (very) important reason for wage rigidity. ${ }^{7}$ This points to the role of collective wage bargaining legislation in Germany.

For highly skilled workers statements $c$ (negative signals), $e$ (fluctuation costs) and $h$ (specific human capital) received very strong support. There is also strong support for statement $e$ and $h$ for skilled workers. Fluctuation costs therefore provide an important explanation for wage rigidity for skilled labor. ${ }^{8}$

\footnotetext{
${ }^{7}$ This confirms Swedish evidence (Agell and Lundborg (1995, 2002), Agell and Bennmarker (2002)).

${ }^{8}$ In large German industrial firms the costs of training in specific human capital can represent up to a one year salary (Franz and Soskice (1995))
} 
Statement $d$ emphasizes the effect of wages on effort. In Germany this statement receives strong support for all skilled groups, while the values of the scores are rather similar. Campbell and Kamlani (1997) found a higher support for less-skilled and blue-collar workers. The responses to statement $b$ on implicit contracts and to $e$ on the relevance of fluctuation costs are very similar in both surveys. This points to the relevance of implicit contracts, of wage related effort variation and fluctuation costs for wage rigidity, despite different degrees of centralization in wage determination in both countries.

Major differences concern the effect of wages on quits and new hires. In the United States statement $g$ (adverse selection model applied to quits) received the strongest support for all skill groups. While responses did not differ much between skilled groups in the German survey, either, the average scores are lower and do not exceed those for the support for explanations based on the effect of wages on effort. One possible explanation for these differences may be due to employment protection legislation. According to the German laws social aspects have to be taken into account in sorting out people to be dismissed. Therefore it might be more difficult to dismiss the least productive workers. Firms in the United States can put less emphasis on social aspects.

Further differences seem to exist in the responses to statement $i$ (workers' resentiments). A possible explanation for the stronger support for statement $i$ in Germany rests on codetermination and collective wage bargaining legislation in Germany. Because of these specific workers' rights, the motive for conflict avoidance may be more relevant in Germany. This finding does not necessarily contradict the assumption of profit maximizing behavior, but indicates more severe constraints, stemming from labor laws, on firm behavior in Germany.

A final difference is related to statement $c$ which emphazises the effect of wages on new hires, which finds much stronger support in Germany. One possible explanation is that in Germany information on wages and the wage structure is more transparent and ready available due to the broader application of labor union contracts. Therefore, German firms might be somewhat more concerned with negative signal effects stemming from wage cuts which undermine their attractiveness for skilled labor. Presumably this is reinforced by the more compressed wage structure in Germany. ${ }^{9}$ The stronger support for statement $f$ (insider-outsider theory) may confirm the view that the insider-outsider theory provides a rationale for collective action rather than a rationale for individual behavior (Fehr (1990)) and is in line with the result for the

\footnotetext{
${ }^{9}$ See Blau and Kahn (1999) and Fitzenberger (1999).
} 
United States that a much stronger support for statement $f$ is found in unionized firms.

To shed some more light on the relevance of the insider-outsider-theory, respondents were asked whether workers would agree upon "pay moderation" either "for keeping their own working place" or "for creating additional working places". Respondents were given three categories of responses: yes, no, and not known for certain. Table IV reports the results. The message is impressive: While, in the opinion of employers, a majority of workers would comply with lower pay in order to secure their own working place, but very few workers in order to create additional employment. These results, together with the support for statement $f$ (harassment), provide support for insider-outsider mechanism in Germany.

To test the relevance of firm characteristics for the responses, ordered probit models for each statement were estimated. Table V reports whether a variable has proved to be significantly different from zero at the five percent level in the ordered probit model. In the case of a significant coefficient Table $\mathrm{V}$ reports + , and otherwise -. Firm characteristics play a significant role in respondents' support of some but not all statements on wage rigidity as indicated also by the bivariate tests by Campbell and Kamlani (1997) and Agell and Lundborg $(1995,2002) .{ }^{10}$ Firms joining the bargaining employers' association significantly more often support statement $a$, which emphasizes the relevance of labor union contracts for wage rigidity. There is no difference between those firms which voluntarily apply these contracts and those which do not at all apply (the reference category).

Turning to the relevance of efficiency wage considerations, there is further evidence that the application of labor union contracts affects the support for statement $e$ (adverse selection in quits; for (less) skilled workers), $d$ (negative effort variation; for less skilled workers), $h$ (specific human capital; for highly skilled workers) and $g$ (adverse selection in dismissals; for skilled workers). Because all these statements rely on efficiency wages as a reason for wage rigidity, the findings seem to indicate that individual firms participating in the system of central wage bargaining do not fear that wage reductions lead to more quits, higher fluctuation costs, and the like. Since lowering wages in labor union contracts would apply to all of these firms, its specific impact on an individual firm is not that important.

\footnotetext{
${ }^{10}$ In addition to the firm characteristics reported in Table V, we tested the influence of the skill structure, profit expectations in 2000 compared to 1998/1999 and the share of flexible pay components. However, we could not find any evidence for the relevance of these variables.
} 
Those firms who report recruitment difficulties for skilled labor, support efficiency wage models with a higher probability, thereby reducing the room for wage cuts for the workers employed. Smaller firms have significantly less fear that wage reduction leads to higher fluctuation costs for highly skilled workers (statement $e$ ) and has a higher probability of supporting statement $h$ (specific human capital) for medium and highly skilled labor. Therefore, in these firms specific human capital aspects seem to dominate the role of transaction costs as a reason for wage rigidity.

There are significant industry, firm size and regional effects for some statements. With the exception of statement $e$ (fluctuation costs) for the highly skilled there are no important firm size effects. The existence of workers councils reduces the support for the explanations emphasizing the effect of wages on effort (statement $d$ ), of wages on fluctuation (statement $e$ ) and of wages for new hires (statement $c$ ). The absence of any measurable effect of workers' councils on the explanation of wage igidity for highly skilled workers stems from the fact that, as a rule, these workers are not represented by workers councils. In summing up, the following explanations for wage rigidity put forward by economic theory are approved by survey respondents: In both countries firms support implicit contract theory as an explanation for wage rigidity for less skilled worker as well as turnover costs and a negative influence of wage reduction on workers effort for all skill groups. Major differences between firms in Germany and the United States concern insider-outsider behavior, labor union contracts, and explanations based on specific human capital and adverse selection considerations.

\section{The relationship between the statements on wage rigidity}

Each theory may, in principle, provide a possible explanation for wage rigidity, but, different theories might be complements or substitutes in practice. Wage rigidity resulting from labor union contracts may be observed even in the absence of such contracts because of the existence of unobservable implicit contracts. Various efficiency wage arguments may together raise explanatory power than one specific efficiency wage theory alone, compared to insider-outsider considerations, for example. If respondents support two statements, a positive relationship between firm responses would indicate that the influence of one of these two statements may, in fact, be small. Otherwise, if there is no measurable relationship between two statements, each of the two theories behind the statement has its own power in explaining wage rigidity. Finally, a negative relationship indicates that more support for one statement reduces the support for the other. In those cases the two theories may not be relevant at the same time.

While Campbell and Kamlani (1997) only asked firms to indicate the most important statement for explaining wage rigidity, our correlation analysis provides an attempt to 
study the relationships between different explanations. Respondents were asked about their view on nine statements for three worker groups. Taken together one obtains 351 possible bivariate relations, which are quantified with Goodman's and Kruskal's $\gamma$. This measure of correlation takes into account the ordered nature of the responses. It varies between minus and plus one. For example, a value of 0.7 implies that from 100 firms which give full support for a specific statement, 70 firms do so for another statement, too. For practical reasons and space restrictions, table VI reports 27 correlation values between the worker categories for each statement and 108 correlation values between the statements for each worker group. ${ }^{11}$

The following findings deserve attention. Firstly, there is a skill specific pattern with respect to the reason of wage rigidity (part 1 of table VI). The reasons for wage igidity are very similar between skilled and highly skilled labor for all nine statements, and fairly similar for medium and less skilled labor. While the correlation between less and highly skilled labor is also significant, the numerical values, with the only exceptions of statement $i$ and $f$, are lower. Secondly, the five statements emphasizing different versions of efficiency wages (statement $c, d, e, g$ and $h$ ) are positively correlated for all worker categories, with relatively high numerical values. These findings suggest that the contribution of an additional version of efficiency wages for explaining wage rigidity seems to be rather small, although each of the five statements receives a high average score. Thirdly, there is a positive correlation between labor union contracts and implicit contracts explanations for wage rigidity for all skill groups. This finding suggests that workers' desire for stable wages is met in part by labor union contracts. Fourthly, there is mixed evidence on the correlation between labor union contracts and statements based on efficiency wages. This suggests that labor union contracts as well as efficiency wages provide a rationale for wage rigidity on its own. Labor union contracts seem to be no substitute for efficiency wages. The same seems to be true for the relationship between implicit contracts and efficiency wages. Although there are some positive values of correlation between efficiency wage and implicit contract explanations, the numerical values are rather small. Hence, each of these three basic theoretical explanations contribute independently to the understanding of wage rigidity. Fifthly, insider-outsider theory and conflict avoidance as possible explanations of wage rigidity are positively correlated with each other and with the efficiency wage explanations. The additional explanatory power of these two

\footnotetext{
${ }^{11}$ The other values deal with correlation between a statement for skill group A and another statement for skill group B. It is well known that labor demand between skill groups is not independent from each other, see Hamermesh (1993). Wage rigidity in the group of less skilled might enhance the demand for skilled labor if these two types of skills are substitutes. Despite its importance for policy reasons we are not aware of any study, which links skill specific explanations of wage rigidity and skill specific labor demand.
} 
theories, given the efficiency explanations, is lower compared to its average and unconditional explanatory power as measured by the average score. But to some extent these findings confirm the relevance of fluctuation costs, specific human capital and wage related effort variation for the bargaining power of insiders and the conflict avoidance strategy by firms.

\section{Pay differentials in labor union contracts}

According to survey respondents, labor union contracts are an important reason for wage rigidity in Germany. Firms applying such contracts are asked, whether they plan to escape from industry level wage bargaining. 85 percent of survey respondents had no plans in that direction. From the remaining firms 39 percent planned to withdraw membership of the employer association, 24 percent planned to outsource parts of the production and 25 planned to bargain directly with the union. From these answers it seems reasonable to conclude that there is some limited pressure on labor union contracts possibly caused by the wage rigidity induced by negotiated wages. This may be the reason for the observed trend on negotiating more flexible pay structures in the annual bargaining rounds since some years. Labor union contracts nowadays more often contain hardship clauses and the possibility for lower pay for new hires and long termed unemployed persons. Whether there exist such possibilities for pay differentiation in labor union contracts and, if so, to what extent firms, applying labor union contracts, take advantage of this flexibility is reported in table VI which contains the questions and the distribution of answers of respondents on hardship clauses, reduced pay for new hires, and reduced pay for long-term unemployed.

Only 11 to 15 percent of the respondents confirm the existence of these flexible pay structures in labor union contracts, which is not that much. Surprisingly, however, the majority of firms which can take advantage pay differentiation do not make use of it. There are two possible explanations for that finding. Firstly, at the time the survey was taken (1999) Germany was not in an economy wide recession, hence there was no urgent need for applying the hardship clause. Secondly, differentiated pay with respect to new hires and long term unemployed may be considered as being unfair, a result which has been found also by Campbell and Kamlani (1997), Bewley (1999) and Agell and Lundborg (2002). As a result of our survey the overwhelming share of firms which did not take advantage of differentiated pay, answered that there was no economic necessity to do and only a minority feared disadvantages on the labor market (multiple answers were possible). This results holds for hardship clauses as well as for differentiated pay for new hires and/or for long-term unemployed. Since the number of respondents for these questions is rather small the results should be taken with some caution. Nevertheless, they are in line with the adverse selection model as applied to new hires and the relevance of fairness considerations in pay determination. 


\section{Conclusions}

This study joins the literature which investigates the empirical relevance of prominent explanations for wage rigidity, such as contract theory, implicit contract theory, efficiency wage theories, fair wage theory and insider-outsider theory. Our study extends the existing literature by basing the findings on thorough econometric methods and a more adequate, because larger and randomly selected, data set. In addition, we analyze the statistical correlation between various explanations for wage rigidity, because, say, two different explanations may by themselves provide a rationale for not cutting wages on their own, but lose part of their explanatory power when both are relevant. Furthermore we compare explanations for wage rigidity between Germany and the United States, two countries with diverse labor market legislation.

While the economic rationale for wage rigidity may be independent of national legislation, the relevance of each of these explanations may not. Depending on national labor legislation the role of any of these explanations for wage rigidity may differ. The bargaining power of employees and their unions will depend on employment protection, codetermination and collective wage bargaining legislation. Since German workers enjoy a higher degree of employment protection than American workers do and codetermination and collective bargaining is quite common in Germany, their bargaining power might be higher, especially in collective wage bargaining rounds. Differences in legislation may also indirectly influence the relevance of efficiency wage explanations for wage rigidity, because more strict employment protection legislation or a wider application of labor union contracts might impose more restrictions on firms wage policies.

We surveyed 801 German firms and asked for their viewpoint with respect to the relevance of various explanations for wage rigidity. Moreover, we compared our results with those obtained by Campbell and Kamlani (1997) for the United States, but taking into account legal peculiarities of the German labor market system for wage determination. German firms strongly support labor union contracts as an explanation for wage rigidity for (less) skilled workers. Specific human capital and negative signals for new hires received strong support for highly skilled employees. Campbell and Kamlani (1997) found the strongest support for the adverse selection model as applied to quits for highly skilled white collar workers. This is not the case in our study, which seems to be the consequence of stronger employment protection legislation in Germany.

In both countries firms support implicit contract theory as an explanation for wage rigidity for less skilled worker as well as turnover costs and a negative influence of wage reduction on workers effort for all skill groups. Compared to the US-evidence, insider-outsider behavior and labor union contracts are more relevant for the explana- 
tion of wage rigidity from the viewpoint of German firms, which hints to the higher degree of unionization in Germany compared to the United States. The German experience has some similarities with the Swedish (Agell and Bennmarker, 2002, Agell and Lundborg, 2002), where unionization is even higher than in Germany. Despite the influence of labor market institutions and labor legislation, however, the economic rationale for wage rigidity has its own weight. The support from German and US firms for explanations based on the impact of wages on effort and implicit contract theory is not that different.

Different causes of wage rigidity are related to each other. There is a positive correlation between labor union contracts and implicit contracts explanations for wage $\dot{\mathbf{i}}-$ gidity for all skill groups. This finding suggests that workers' desire for stable wages is met in part by labor union contracts. There is also a relatively high correlation between five causes based on variants of efficiency wage theories. The findings suggest that the contribution of an additional version of efficiency wages for explaining wage rigidity is rather small, although each of the five causes received a high average score. Furthermore, labor union contracts and efficiency wage explanations provide a ationale for wage rigidity on its own. Labor union contracts are no substitute for efficiency wage explanations on wage rigidity and efficiency wage explanations provide no substitute for implicit contracts. Each of these three basic theoretical explanations contributes independently to the understanding of wage rigidity.

\section{Appendix}

The present study uses a large firm address data base at the Center for European Economic Research (ZEW), Mannheim Germany. The data base is an original data set established by a German credit rating association (Verband der Vereine Creditreform (VVC)) that has been widely used by economists (see for example Harhoff, Stahl and Woywode, 1998). These data set contains information on firm size and industry of the most important activities of the firm. In the industries selected for the purpose of the current study the data base contained the addresses of 160,607 firms with more than 9 employees in December 1999. The industries chosen represent manufacturing and service industries and firms from the sector of firm related services. From these addresses 5,100 were selected randomly on the basis of a two way stratification scheme by five industries and six firm size categories.

Larger firms and firms in chemical and finance and insurance were oversampled to get a reasonable number of responses in these cells. Table VIII contains the number of randomly selected firms in each industry and firm size cell, their share in the population and the number of respondents. Under the assumption of random response weight factors had been calculated for inferences about the original firm population. 


\section{References}

Acemoglu, Daron, Philippe Aghion, and Giovanni L. Violante, "Deunionization, Technical Change and Inequality," Carnegie Rochester Conference Series on Public Policy: a Bi-Annual Conference Proceedings, 55 (2001), S. 229-264.

Agell, Jonas, and Helge Bennmarker, Wage Policy and Endogenous Wage Rigidity: A Representative View From the Inside, CESifo Working Papers No. 751, Munich.

Agell, Jonas, and Per Lundborg, "Theories of Pay and Unemployment: Survey Evidence from Swedish Manufacturing Firms," Scandinavian Journal of Economics, XCVII (1995), 295-307.

Agell, Jonas, and Per Lundborg, "Survey Evidence on Wage Rigidity and Unemployment: Sweden in the 1990s", forthcoming Scandinavian Journal of Economics (2002).

Altonji, Joseph G., and Paul J. Devereux, The Extent and Consequences of Downward Nominal Wage Rigidity, NBER Working Paper, 7236 (1999).

Beissinger, Thomas, and Christoph Knoppik, „Downward Nominal Rigidities in West-German Earnings 1975 - 1995,“ German Economic Review, 2 (2001), 385-417.

Bertola, Giuseppe, "Microeconomic Perspectives on Aggregate Labor Markets," in: Orley Ashenfelter, David Card, eds., Handbook of Labor Economics, Vol. 3C (Amsterdam: Elsevier, 1999), 2982-3024.

Bewley, Truman F., "Depressed Labor Markets as Explained by Participants," The American Economic Review, LXXXV (1995), 250-54.

—_, "Why Not Cut Pay?", European Economic Review, 42 (1998), 459-490.

—, Why Wages Don't Fall During A Recession, (Cambridge, Mass.: Harvard University Press, 1999).

Blau, Francine D., and Lawrence M. Kahn, "Institutions and Laws in the Labor Market,“ in: Orley Ashenfelter, David Card, eds., Handbook of Labor Economics, Vol. 3C (Amsterdam: Elsevier, 1999), 1399-1461.

Blinder, Alan S., and Don H. Choi, "A Shred of Evidence on Theories of Wage Stickiness," The Quarterly Journal of Economics, 105 (1990), 1003-15.

Campbell, Carl M., and Kunal S. Kamlani, "The Reasons for Wage Rigidity: Evidence from a Survey of Firms," The Quarterly Journal of Economics, 3 (1997), $759-89$. 
Card, David, and Dean Hyslop, "Does Inflation "Grease the Wheels of the Labor Market”?," in: Christina D. Romer and David H. Romer, eds., Reducing Inflation : Motivation and Strategy, (Chicago: The University of Chicago Press, 1997), 71-114.

Fehr, Ernst, "Cooperation, Harassment, and Involuntary Unemployment: Comment," The American Economic Review, 80 (1990), 624-630.

Fehr, Ernst, and Lorenz Götte, "The Robustness and Real Consequences of Nominal Wage Rigidity, “ CESifo working paper series, 335 (2000).

Fitzenberger, Bernd, Wages and Employment Across Skill Groups: An Analysis for West Germany, (Heidelberg: Physica, 1999).

Franz, Wolfgang, Arbeitsmarktökonomik, 4. ed. (Berlin: Springer, 1999).

Franz, Wolfgang, and David Soskice, "The German Apprenticeship System,“ in: Friedrich Buttler, Wolfgang Franz, Ronald Schettkat, eds., Institutional Frameworks and Labor Market Performance: Comparative Views on the US and German Economies, (London: Routledge, (1995), 208-34.

Hamermesh, Daniel S., Labor Demand, (Princeton, NJ : Princeton Univ. Press, 1993).

Harhoff, Dietmar, Konrad O. Stahl, and Michael Woywode, "Legal Form, Growth and Exit of West German Firms: Empirical Results for Manufacturing, Construction, Trade and Service Industries," The Journal of Industrial Economics, XLVI (1998), 453-488.

Howitt, Peter, "Looking inside the labor market: A review article," Journal of Economic Literature XL (2002), 125-138.

Kahn, Shulamit B., "Evidence of Nominal Wage Stickiness from Microdata," The American Economic Review, 87 (1997), 993-1008.

Kaufman, Roger T., "On Wage Stickiness in Britain's Competitive Sector," British Journal of Industrial Relations, XXII (1984), 101-12.

Malcomson, James M., "Individual Employment Contracts", in: Orley Ashenfelter, David Card (eds.), Handbook of Labor Economics, Vol. 3C (Amsterdam: Elsevier, 1999), 2291-2372. 


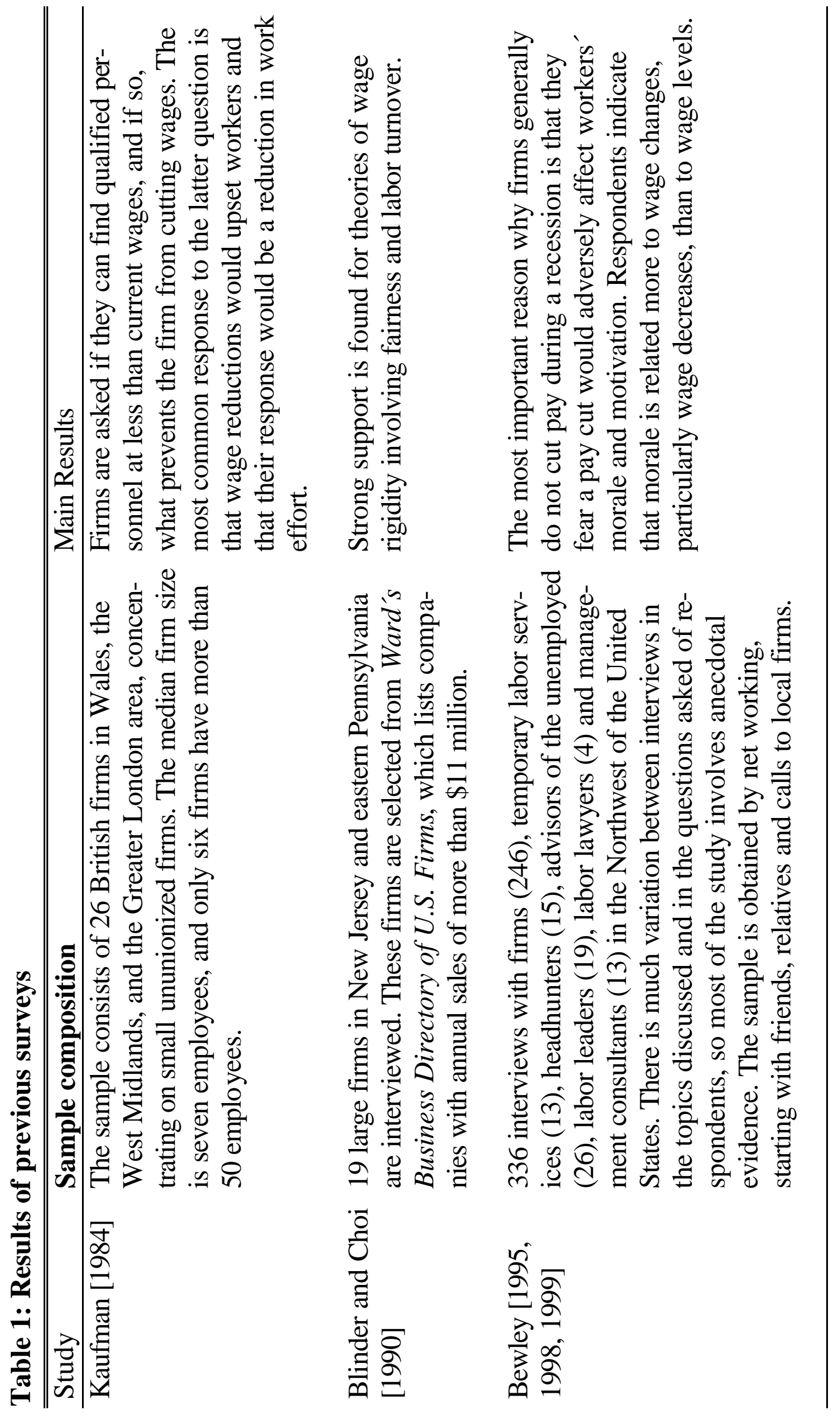




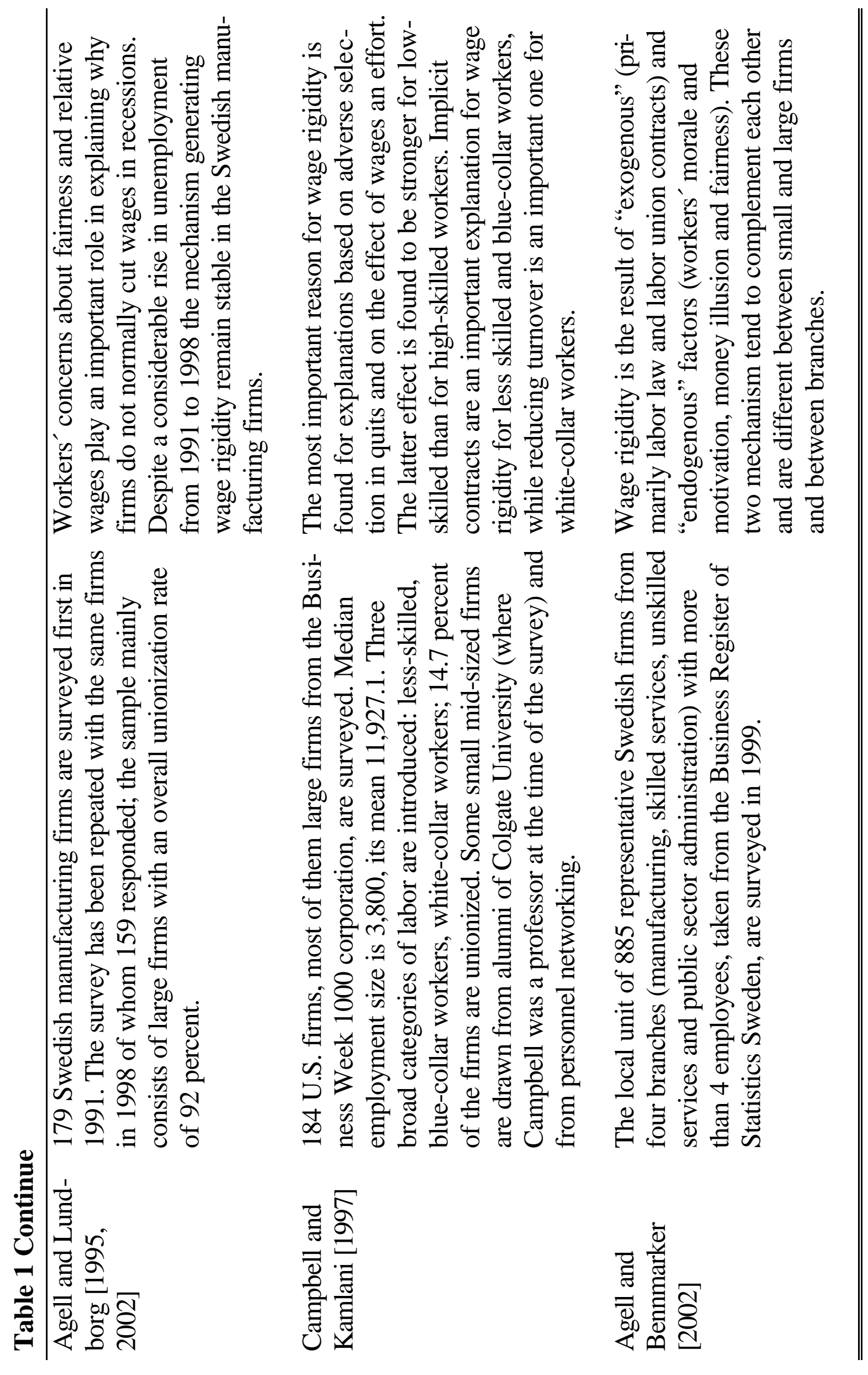


Table 2: Descriptive statistics

\begin{tabular}{|c|c|c|c|}
\hline Variable (Type of Variables) & $\begin{array}{l}\text { Sample mean } \\
\text { Percentages }\end{array}$ & $\begin{array}{l}\text { Population } \\
\text { mean }^{a} \\
\text { Percentages }\end{array}$ & " Observations $^{b}$ \\
\hline \multicolumn{4}{|c|}{ Legal background for a labor union contract $(0,1)$} \\
\hline No labor union contract (reference cat.) & 43.0 & 62.0 & 797 \\
\hline Membership in the employer association & 39.5 & 22.5 & 797 \\
\hline Firm specific labor union contract & 4.1 & 2.1 & 797 \\
\hline Governmental binding union contract wages ${ }^{c}$ & 3.9 & 3.4 & 797 \\
\hline Reference clause in individual contracts & 2.4 & 1.4 & 797 \\
\hline Voluntary application & 7.0 & 8.6 & 797 \\
\hline \multicolumn{4}{|c|}{ Only for firms applying a labor union contract } \\
\hline $\begin{array}{l}\text { Are there plants without application?(0 } \\
\text { no,1yes) }\end{array}$ & 12.3 & 12.6 & 454 \\
\hline $\begin{array}{l}\text { Are there pay differences between union and } \\
\text { non union members? }(0 \text { no, } 1 \text { yes })\end{array}$ & 20.1 & 20.6 & 393 \\
\hline \multicolumn{4}{|c|}{ Skill composition of workers (in percent) } \\
\hline Highly skilled workers & 21.9 & 19.8 & 683 \\
\hline Skilled workers & 60.1 & 67.4 & 683 \\
\hline Less skilled workers & 18.0 & 12.8 & 683 \\
\hline \multicolumn{4}{|c|}{ Industrial composition $(0,1)$} \\
\hline Chemical (reference cat.) & 12.6 & 2.3 & 801 \\
\hline Metal- and engine building, electrical industries & 29.5 & 23.4 & 801 \\
\hline Wholesale and retail trade & 15.9 & 43.2 & 801 \\
\hline Finance and insurance & 11.0 & 1.6 & 801 \\
\hline Firm related services & 27.6 & 25.2 & 801 \\
\hline Others (construction, etc.) & 3.5 & 4.3 & 801 \\
\hline
\end{tabular}


Number of employees (firm size categories, 0,1 )

$\begin{array}{lccc}500+\text { employees (reference cat.) } & 22.4 & 3.1 & 799 \\ 200-499 & 17.3 & 4.0 & 799 \\ 100-199 & 16.5 & 5.9 & 799 \\ 50-99 & 15.3 & 11.3 & 799 \\ 20-49 & 14.0 & 26.7 & 799 \\ 10-19 & 14.5 & 49.0 & 799\end{array}$

Location of firms' headquarter $(0,1)$

$\begin{array}{lccc}\text { West Germany (reference cat.) } & 73.1 & 73.8 & 789 \\ \text { East Germany } & 17.2 & 20.3 & 789 \\ \text { Outside Germany } & 9.6 & 5.9 & 789\end{array}$

There is a workers' council in the firm $(0,1)$
Workers' council
52.6
18.4
794

Evidence of recruitment problems for highly skilled workers $(0,1)$
No evidence (reference cat.)
58.6
69.7
753
Evidence
23.1
12.0
753
Strong evidence
18.3
18.6
753

Evidence of recruitment problems for skilled workers $(0,1)$

$\begin{array}{llll}\text { No evidence (reference cat.) } & 48.1 & 45.9 & 772 \\ \text { Evidence } & 29.9 & 29.6 & 772 \\ \text { Strong evidence } & 22.0 & 24.5 & 772\end{array}$

${ }^{a}$ Mean calculated for the population of firms under the assumption of random response.

${ }^{b}$ Number of valid observations for the variable under consideration.

${ }^{c}$,Allgemeinverbindlicherklärung“, i.e. all firms in a region and industry have to apply the labor union contracts of that region and industry. 


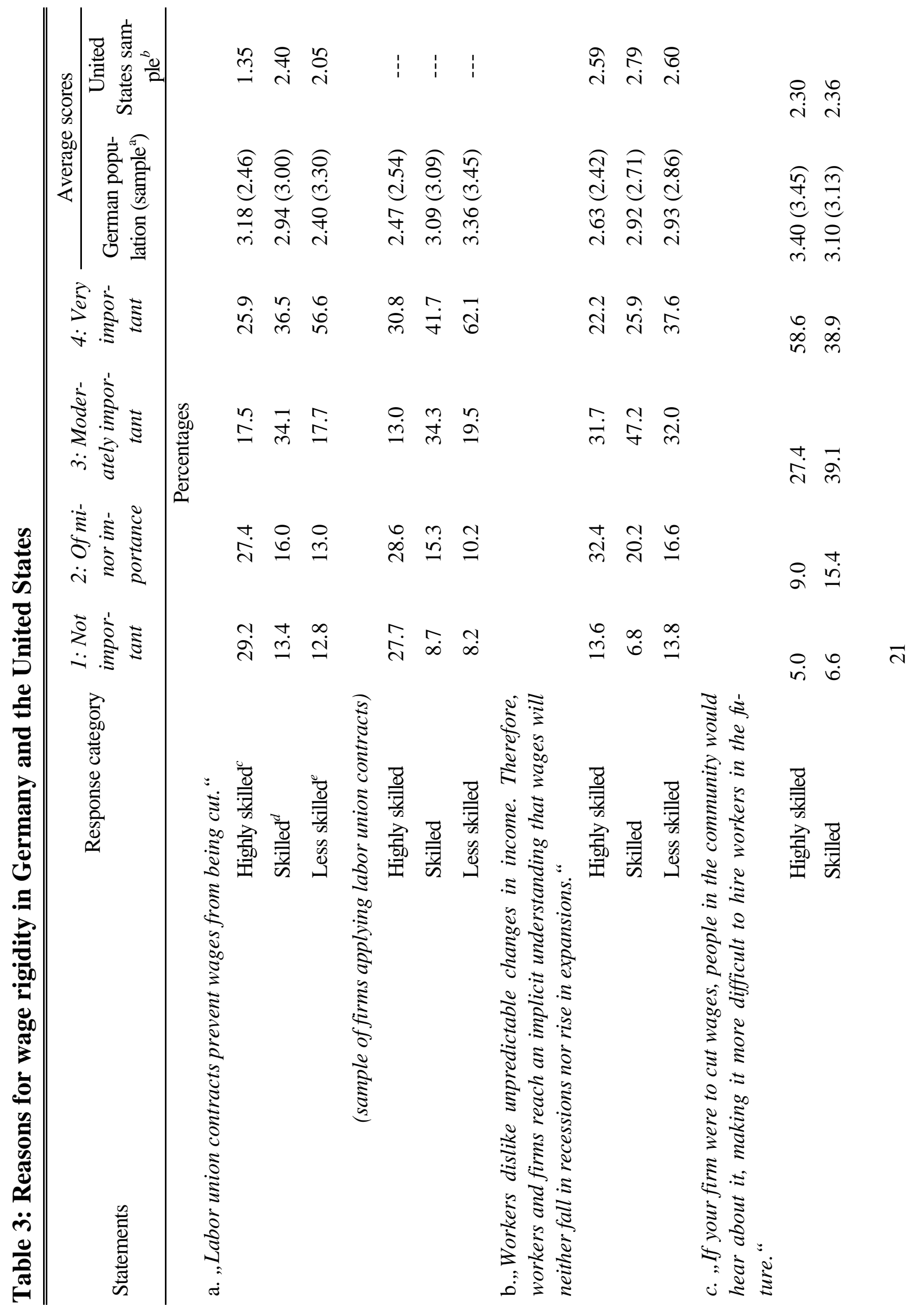




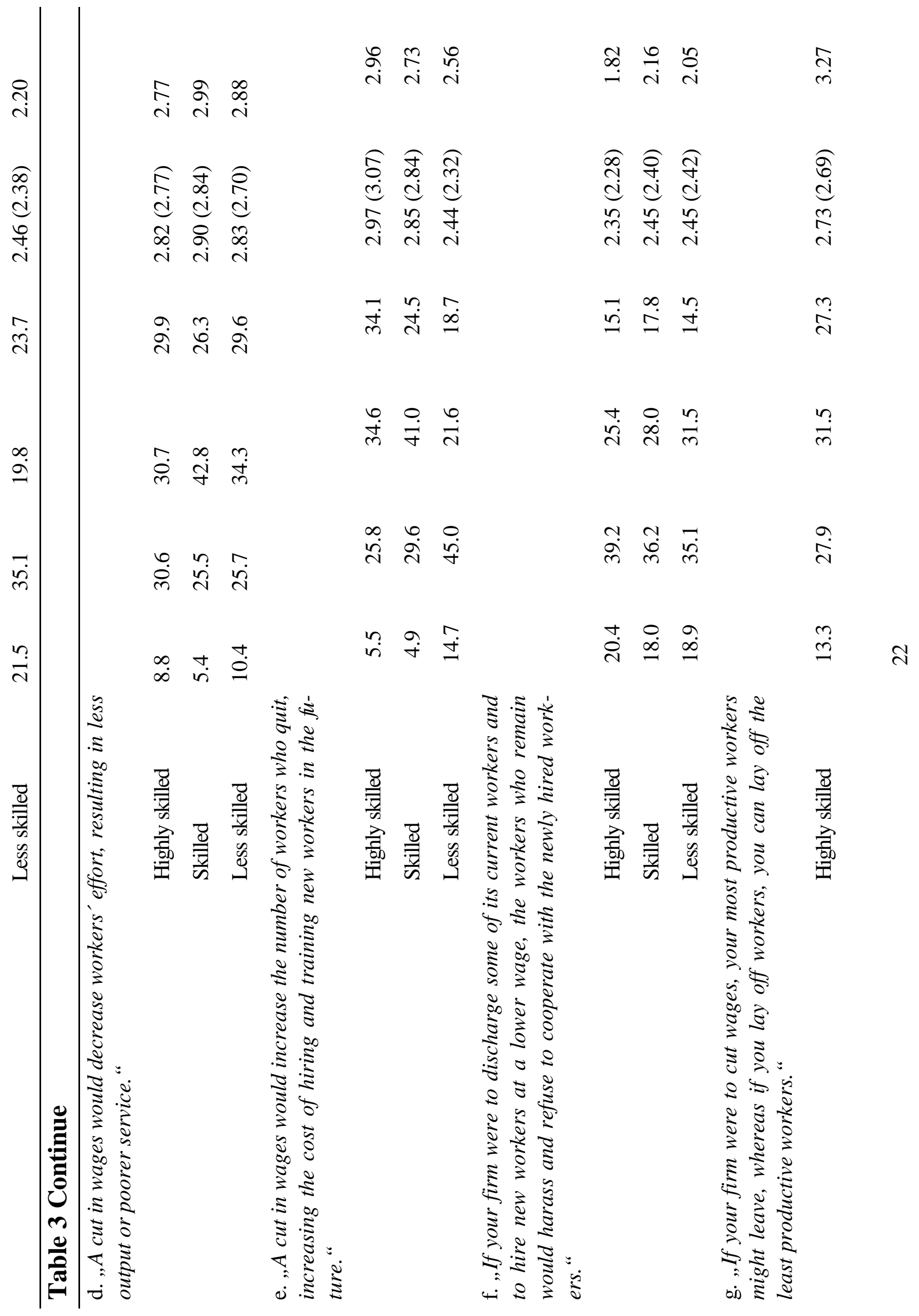




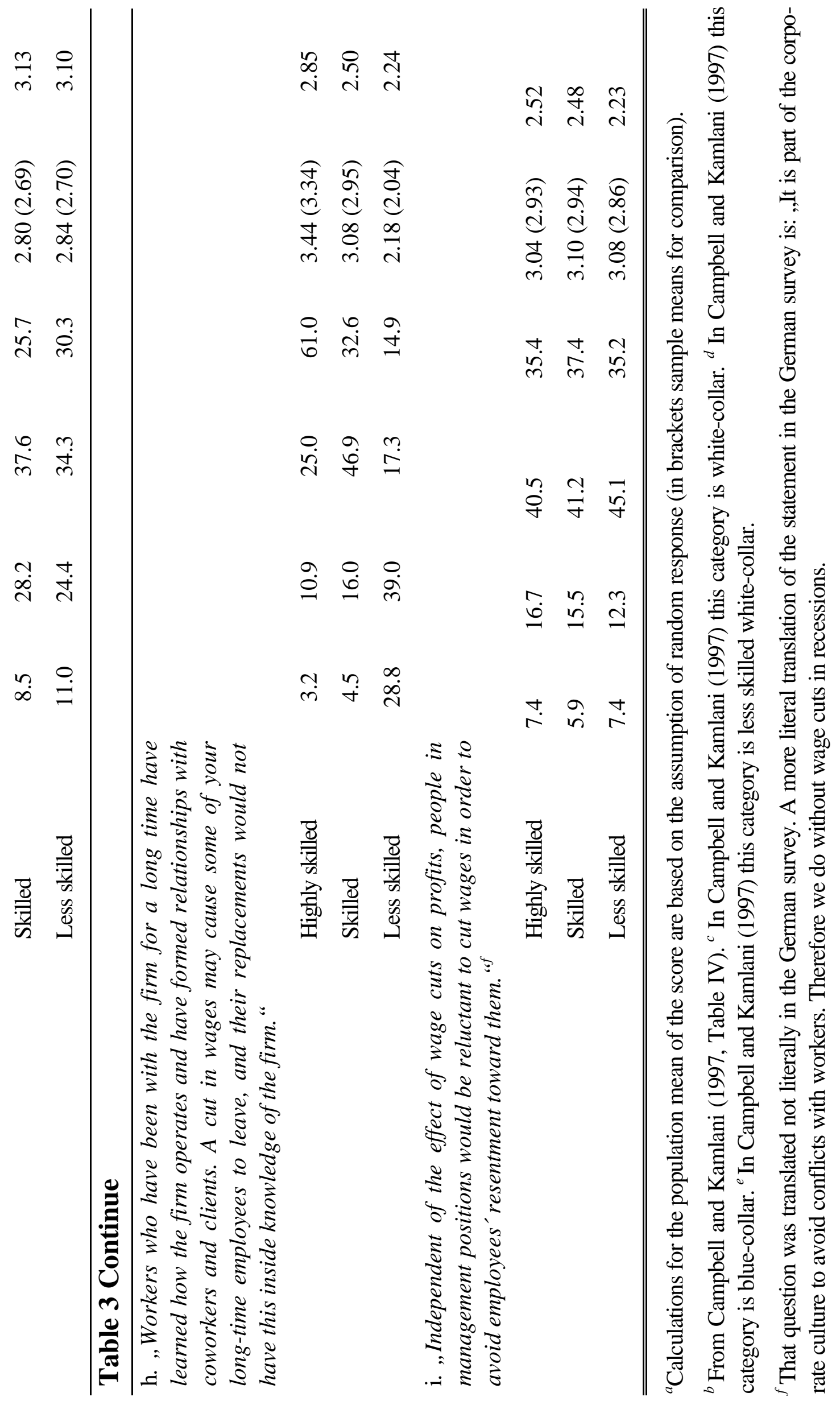


Table 4: Pay moderation and job security

\begin{tabular}{|c|c|c|c|c|}
\hline Response category & Yes & No & Not sure & $\begin{array}{c}\text { Number of } \\
\text { valid observa- } \\
\text { tions }\end{array}$ \\
\hline \multicolumn{5}{|c|}{ Percentages } \\
\hline \multicolumn{5}{|c|}{$\begin{array}{l}\text { „Do you think that the workers in your firm would accept more moderate pay } \\
\text { to secure their own working place?" }\end{array}$} \\
\hline Highly skilled & 38.6 & 23.3 & 38.1 & 776 \\
\hline Skilled & 42.3 & 27.7 & 30.0 & 788 \\
\hline Less skilled & 34.4 & 34.4 & 31.2 & 765 \\
\hline \multicolumn{5}{|c|}{$\begin{array}{l}\text { „Do you think that the workers in your firm would accept more moderate pay } \\
\text { to create additional working places?" }\end{array}$} \\
\hline Highly skilled & 7.2 & 67.3 & 25.4 & 770 \\
\hline Skilled & 5.8 & 69.3 & 24.9 & 778 \\
\hline Less skilled & 3.6 & 74.9 & 21.5 & 755 \\
\hline
\end{tabular}

Calculations are based on the assumption of random response. 
Table 5: Significant influences on firms support for each explanation on wage rigidity

\begin{tabular}{l|l|l|l|l|l|l|l|l|l|}
\hline \hline Statement & a. & b. & c. & d. & e. & f. & g. & h. & i. \\
Skill group & H S L L S L L S L L L L H S L & H S L & H S L L H L L H S L \\
\hline
\end{tabular}

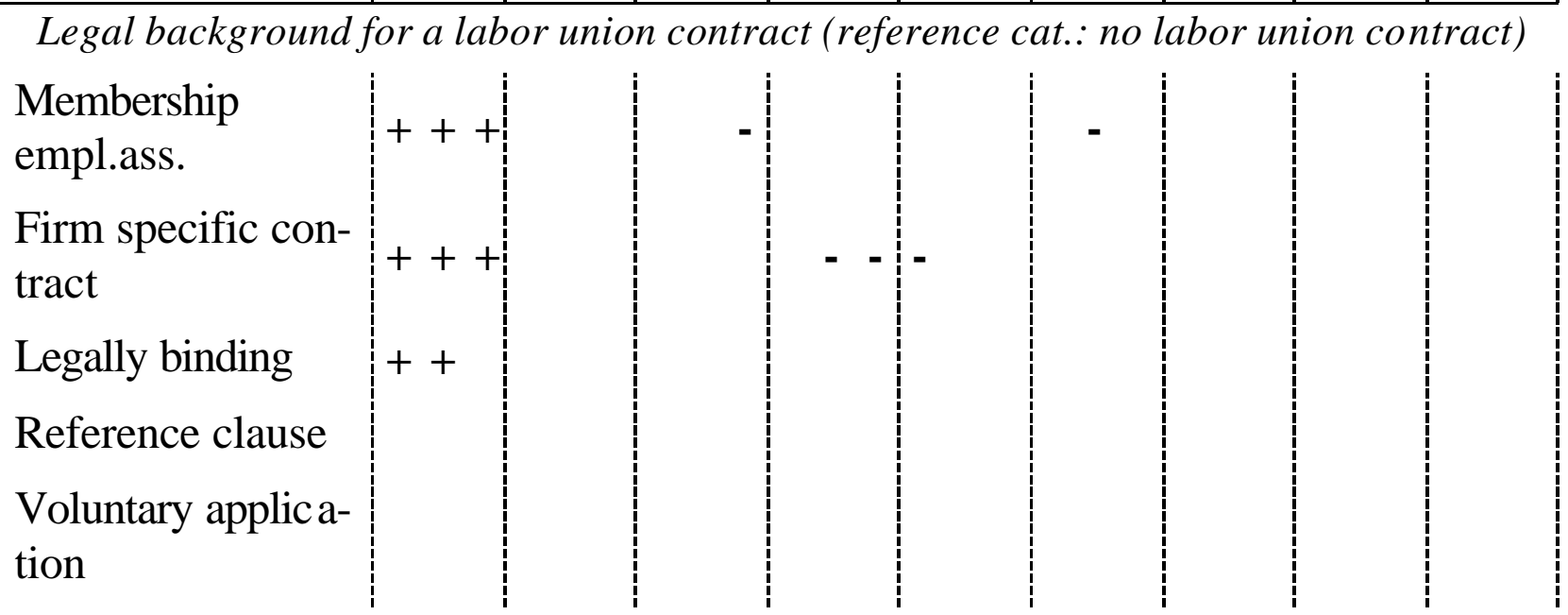

Industries (reference cat.: chemical)

Metal-, electrical
ind.
Trade
Finance and in-
surace
Firm related serv-
ices
Others (construc-
tion, etc.)

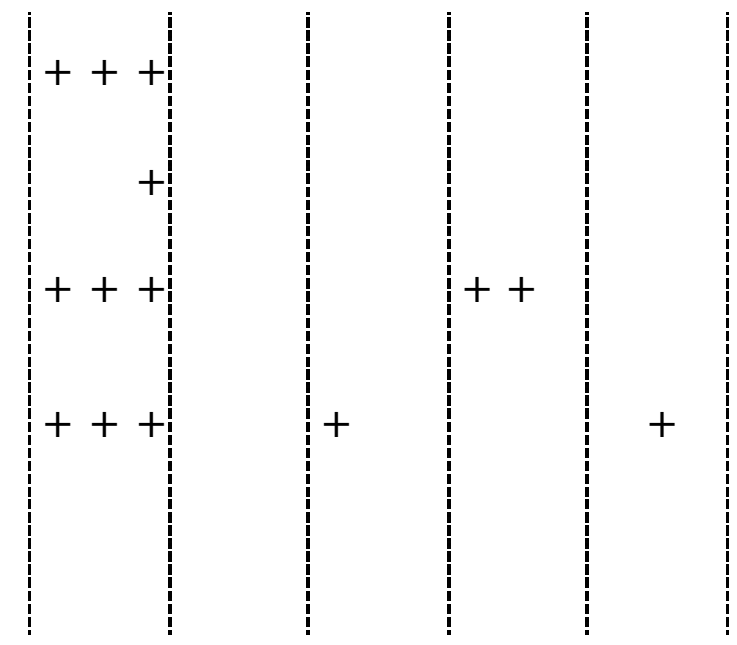

Firm size (reference cat.: 500+)

10-19 employees 20-49

50- 99

100-199

200- 499

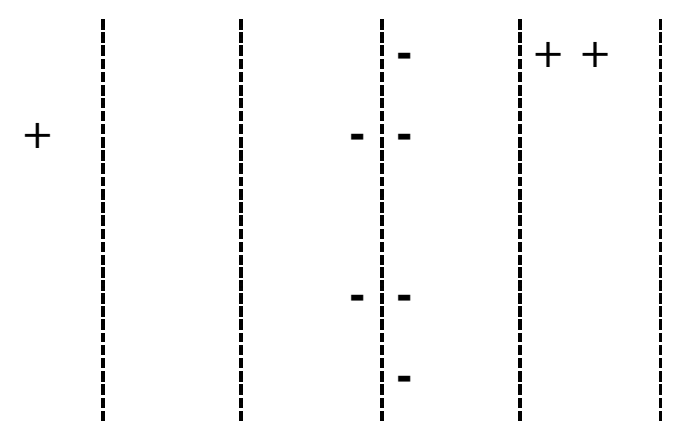

Location of firms' headquarter (reference cat.: West Germany)

East Germany

Outside Germany 
Table 5 Continue

There is a workers' council in the firm (reference cat.: no workers' council)

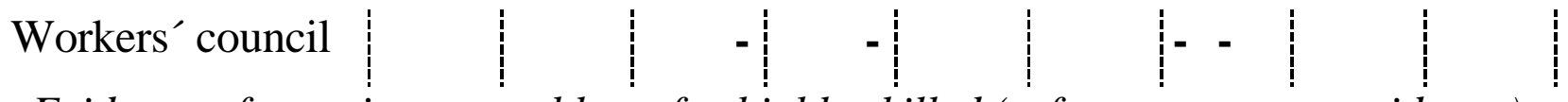

Evidence of recruitment problems for highly skilled (reference cat.: no evidence)

Evidence

Strong evidence

Evidence of recruitment problems for skilled (reference cat.: no evidence)

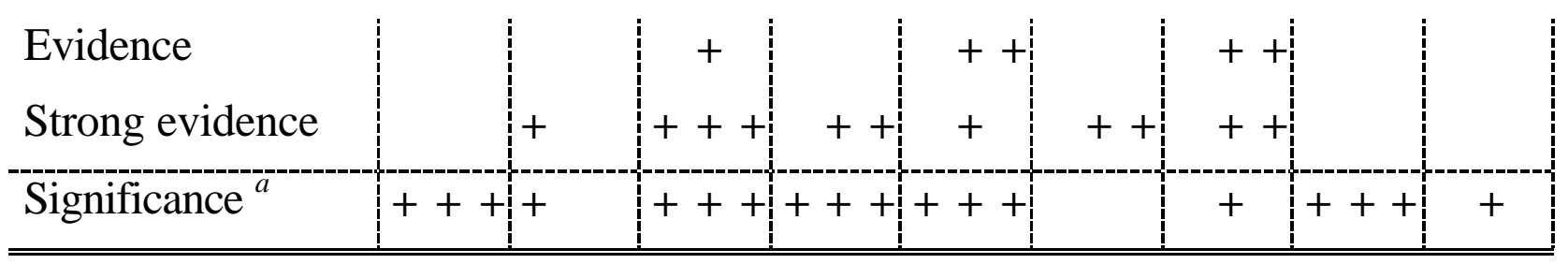

+ / - a positive / negative coefficient of one variable was different from zero at the 5 percent level in an ordered probit model.

a The significance of all explanatory variables in the ordered probit model was tested based on a likelihood ratio test, + indicates that all explanatory variables together are significant at the 5 percent level. 
Table 6: Correlation analysis

\begin{tabular}{cccc}
\hline \hline \multicolumn{3}{c}{ Part 1: Correlation between the skill groups for each statement (?) } & \\
\hline Statement & $\mathrm{L}-\mathrm{S}$ & $\mathrm{L}-\mathrm{H}$ & $\mathrm{S}-\mathrm{H}$ \\
a. & $\mathbf{0 . 6 5}$ & $\mathbf{0 . 3 3}$ & $\mathbf{0 . 8 8}$ \\
b. & $\mathbf{0 . 7 5}$ & $\mathbf{0 . 2 3}$ & $\mathbf{0 . 8 1}$ \\
c. & $\mathbf{0 . 7 2}$ & $\mathbf{0 . 2 5}$ & $\mathbf{0 . 8 5}$ \\
d. & $\mathbf{0 . 7 2}$ & $\mathbf{0 . 3 8}$ & $\mathbf{0 . 9 3}$ \\
e. & $\mathbf{0 . 7 2}$ & $\mathbf{0 . 3 7}$ & $\mathbf{0 . 8 8}$ \\
f. & $\mathbf{0 . 8 3}$ & $\mathbf{0 . 6 0}$ & $\mathbf{0 . 9 3}$ \\
g. & $\mathbf{0 . 7 9}$ & $\mathbf{0 . 5 6}$ & $\mathbf{0 . 9 6}$ \\
h. & $\mathbf{0 . 7 0}$ & $\mathbf{0 . 2 4}$ & $\mathbf{0 . 9 1}$ \\
i. & $\mathbf{0 . 8 8}$ & $\mathbf{0 . 7 4}$ & $\mathbf{0 . 9 6}$
\end{tabular}

Part 2: Correlation between statements for each skill group (?) ${ }^{a}$

Less skilled workers (L)

\begin{tabular}{ccccccccc}
\hline Statement & b. & c. & d. & e. & f. & g. & h. & i. \\
a. & $\mathbf{0 . 2 7}$ & $\mathbf{- 0 . 0 4}$ & $\mathbf{0 . 1 5}$ & $\mathbf{0 . 1 0}$ & $\mathbf{0 . 0 8}$ & $\mathbf{0 . 1 9}$ & $-\mathbf{- 0 . 1 3}$ & $\mathbf{0 . 0 1}$ \\
b. & --- & $\mathbf{0 . 1 2}$ & $\mathbf{0 . 2 3}$ & $\mathbf{0 . 1 6}$ & $\mathbf{0 . 1 3}$ & $\mathbf{0 . 0 6}$ & $\mathbf{0 . 1 9}$ & $\mathbf{0 . 1 3}$ \\
c. & & --- & $\mathbf{0 . 4 7}$ & $\mathbf{0 . 5 3}$ & $\mathbf{0 . 1 0}$ & $\mathbf{0 . 2 6}$ & $\mathbf{0 . 5 0}$ & $\mathbf{0 . 2 2}$ \\
d. & & & --- & $\mathbf{0 . 5 5}$ & $\mathbf{0 . 2 7}$ & $\mathbf{0 . 4 3}$ & $\mathbf{0 . 4 2}$ & $\mathbf{0 . 4 4}$ \\
e. & & & & --- & $\mathbf{0 . 2 0}$ & $\mathbf{0 . 2 9}$ & $\mathbf{0 . 4 8}$ & $\mathbf{0 . 2 0}$ \\
f. & & & & & --- & $\mathbf{0 . 3 8}$ & $\mathbf{0 . 2 2}$ & $\mathbf{0 . 1 0}$ \\
g. & & & & & & --- & $\mathbf{0 . 3 3}$ & $\mathbf{0 . 1 6}$ \\
h. & & & & & & & --- & $\mathbf{0 . 2 4}$ \\
\hline
\end{tabular}


Skilled workers (S)

\begin{tabular}{ccccccccc}
\hline Statement & b. & c. & d. & e. & f. & g. & h. & i. \\
a. & $\mathbf{0 . 3 6}$ & $\mathbf{- 0 . 0 4}$ & $\mathbf{0 . 0 4}$ & $-\mathbf{- 0 . 0 1}$ & $\mathbf{0 . 0 9}$ & $\mathbf{0 . 1 9}$ & $\mathbf{0 . 0 8}$ & $\mathbf{- 0 . 0 4}$ \\
b. & --- & $\mathbf{- 0 . 0 1}$ & $\mathbf{0 . 1 3}$ & $\mathbf{0 . 1 4}$ & $\mathbf{0 . 0 7}$ & $\mathbf{0 . 1 9}$ & $\mathbf{0 . 1 6}$ & $\mathbf{0 . 2 8}$ \\
c. & & --- & $\mathbf{0 . 5 8}$ & $\mathbf{0 . 5 4}$ & $\mathbf{0 . 1 4}$ & $\mathbf{0 . 1 9}$ & $\mathbf{0 . 3 8}$ & $\mathbf{0 . 3 2}$ \\
d. & & & --- & $\mathbf{0 . 5 9}$ & $\mathbf{0 . 1 7}$ & $\mathbf{0 . 3 4}$ & $\mathbf{0 . 6 0}$ & $\mathbf{0 . 3 6}$ \\
e. & & & & --- & $-\mathbf{0 . 0 1}$ & $\mathbf{0 . 3 9}$ & $\mathbf{0 . 5 6}$ & $\mathbf{0 . 3 1}$ \\
f. & & & & & --- & $\mathbf{0 . 3 0}$ & $\mathbf{0 . 3 2}$ & $\mathbf{0 . 2 1}$ \\
g. & & & & & & --- & $\mathbf{0 . 4 1}$ & $\mathbf{0 . 1 1}$ \\
h. & & & & & & & --- & $\mathbf{0 . 3 7}$ \\
\hline & & & Highly skilled workers $(\mathrm{H})$ & & & \\
\hline Statement & b. & c. & d. & e. & f. & g. & h. & i. \\
a. & $\mathbf{0 . 2 7}$ & $\mathbf{0 . 0 4}$ & $\mathbf{0 . 1 2}$ & $-\mathbf{- 0 . 1 3}$ & $\mathbf{0 . 1 2}$ & $\mathbf{0 . 1 0}$ & $\mathbf{- 0 . 0 4}$ & $\mathbf{0 . 0 4}$ \\
b. & --- & $\mathbf{0 . 0 9}$ & $\mathbf{0 . 1 1}$ & $\mathbf{0 . 0 5}$ & $\mathbf{0 . 1 8}$ & $\mathbf{0 . 2 3}$ & $\mathbf{0 . 0 9}$ & $\mathbf{0 . 2 4}$ \\
c. & & --- & $\mathbf{0 . 4 7}$ & $\mathbf{0 . 5 1}$ & $\mathbf{0 . 1 9}$ & $\mathbf{0 . 2 1}$ & $\mathbf{0 . 4 2}$ & $\mathbf{0 . 3 2}$ \\
d. & & & --- & $\mathbf{0 . 5 1}$ & $\mathbf{0 . 1 8}$ & $\mathbf{0 . 3 3}$ & $\mathbf{0 . 4 5}$ & $\mathbf{0 . 2 4}$ \\
e. & & & & --- & $\mathbf{0 . 1 3}$ & $\mathbf{0 . 3 0}$ & $\mathbf{0 . 5 8}$ & $\mathbf{0 . 2 3}$ \\
f. & & & & & --- & $\mathbf{0 . 2 5}$ & $\mathbf{0 . 1 3}$ & $\mathbf{0 . 1 2}$ \\
g. & & & & & & --- & $\mathbf{0 . 3 6}$ & $\mathbf{0 . 1 6}$ \\
h. & & & & & & & --- & $\mathbf{0 . 2 6}$ \\
\hline \hline
\end{tabular}

Calculations for the firm population based on the assumption of random response.

${ }^{a}$ ? is Goodman's und Kruskal's gamma for ordered variables calculated with STATA6.0; bold type values are significantly different from zero at the 5 percent level. 


\section{Table 7: Pay differentiation in Labor union contracts (Percentages)}

i. „Does your labor contract contain the possibility of reducing pay in recessions?“

No

87.6
Yes

12.4

„If so: Did your firm take advantage of this possibility in 1998/99?“

No

9.9
Yes

2.5

ii. „Does your labor contract contain the possibility of reducing pay for new hires?“

No

84.5
Yes

15.5

„If so: Did your firm take advantage of this possibility in 1998/99?“
No
Yes
9.6
5.9

iii. „Does your labor contract contain the possibility of reducing pay for hiring long-term unemployed workers?"“
No
Yes
89.0
11.0

„If so: Did your firm take advantage of this possibility in 1998/99?“

$\begin{array}{ll}\text { No } & \text { Yes } \\ 9.3 & 1.7\end{array}$

Calculations based on the assumption of random response. 


\begin{tabular}{|c|c|c|c|c|c|c|c|}
\hline \multirow{2}{*}{ Industry } & & \multicolumn{6}{|c|}{ Firm size } \\
\hline & & $10-19$ & $20-49$ & $50-99$ & 100-199 & $200-499$ & $500+$ \\
\hline \multirow[t]{3}{*}{ Chemical } & 1 & 100 & 100 & 100 & 100 & 100 & 100 \\
\hline & 2 & $16.1 \%$ & $16.7 \%$ & $28.0 \%$ & $38.8 \%$ & $47.0 \%$ & $54.4 \%$ \\
\hline & 3 & 11 & 7 & 11 & 22 & 22 & 28 \\
\hline \multirow{3}{*}{$\begin{array}{l}\text { Metal- and engine building, } \\
\text { electrical industries }\end{array}$} & 1 & 200 & 200 & 200 & 200 & 200 & 200 \\
\hline & 2 & $3.1 \%$ & $3.3 \%$ & $7.2 \%$ & $11.5 \%$ & $15.9 \%$ & $25.5 \%$ \\
\hline & 3 & 22 & 40 & 28 & 44 & 50 & 52 \\
\hline \multirow[t]{3}{*}{ Wholesale and retail trade } & 1 & 200 & 200 & 200 & 200 & 200 & 200 \\
\hline & 2 & $0.8 \%$ & $1.3 \%$ & $4.0 \%$ & $8.7 \%$ & $16.0 \%$ & $24.8 \%$ \\
\hline & 3 & 21 & 16 & 28 & 14 & 19 & 29 \\
\hline \multirow[t]{3}{*}{ Finance and insurance } & 1 & 100 & 100 & 100 & 100 & 100 & 100 \\
\hline & 2 & $14.6 \%$ & $21.2 \%$ & $54.0 \%$ & $59.5 \%$ & $59.2 \%$ & $55.3 \%$ \\
\hline & 3 & 10 & 6 & 8 & 10 & 23 & 29 \\
\hline \multirow[t]{3}{*}{ Firm related services } & 1 & 250 & 250 & 250 & 250 & 250 & 250 \\
\hline & 2 & $2.5 \%$ & $3.9 \%$ & $10.2 \%$ & $18.7 \%$ & $24.9 \%$ & $38.2 \%$ \\
\hline & 3 & 47 & 37 & 42 & 41 & 20 & 34 \\
\hline Others ${ }^{a}$ & 3 & 5 & 6 & 5 & 1 & 4 & 7 \\
\hline
\end{tabular}

1 Number of firms randomly selected per cell

2 Percent of firm population selected per cell

3 Respondents

${ }^{a} 28$ respondents from other industries, selected from a different source. 